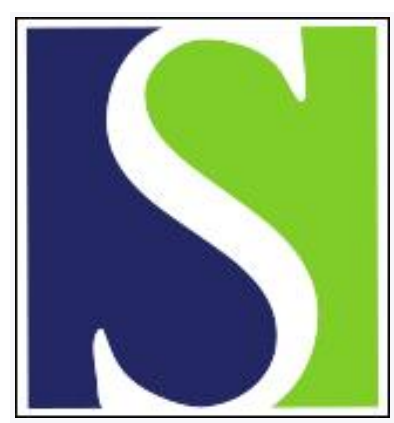

Scand J Work Environ Health 1987;13(3):221-231

https://doi.org/10.5271/sjweh.2059

Issue date: Jun 1987

Kinetics of lead in blood after the end of occupational exposure.

by Schutz A, Skerfving S, Ranstam J, Christoffersson JO

This article in PubMed: www.ncbi.nlm.nih.gov/pubmed/3616551

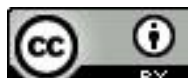




\title{
Kinetics of lead in blood after the end of occupational exposure
}

\author{
by Andrejs Schütz, PhD, ${ }^{1}$ Staffan Skerfving, MD, ${ }^{1}$ Jonas Ranstam, BSc, ${ }^{1}$ \\ Jan-Ove Christoffersson, $\mathrm{PhD}^{2}$
}

\begin{abstract}
SCHÜTZ A, SKERFVING S, RANSTAM J, CHRISTOFFERSSON J-O. Kinetics of lead in blood after the end of occupational exposure. Scand J Work Environ Health 13 (1987) 221-231. The sum of two exponential functions was fitted to the decay of blood lead $(\mathrm{PbB})$ level after the end of lead exposure. For two subjects who had not formerly been occupationally exposed to lead but who had been exposed to a single short heavy dose, the fast compartment (probably soft tissues) had a biological half-time of 27 and $44 \mathrm{~d}$, respectively. For 20 lead workers after the end of occupational exposure, the corresponding median was 29 (range 7-63) d. For 21 ex-lead workers, the median biological half-time of the slow compartment was 5.6 (range $2.3-27$ ) years. There was significant interindividual variation in both the fast and the slow half-time This finding probably means a considerable variation in risk at a certain exposure level. In the lead workers, the $\mathrm{PbB}$ fraction corresponding to the slow compartment had a median as high as 1.8 (range $0.7-2.7$ ) $\mu \mathrm{mol} / \mathrm{l}$, which constituted more than half of the total $\mathrm{PbB}$. This fraction was associated with exposure history, and with the lead level in the skeleton, the latter determined in vivo by an X-ray fluorescence method. The data thus indicate a rather rapid turnover of the skeletal lead pool, a phenomenon which may affect the $\mathrm{PbB}$ level considerably.
\end{abstract}

Key terms: half-time, metabolic model, two-compartment model.

Lead exposure is common in industry. The blood lead $(\mathrm{PbB})$ level is the main parameter used for the biological monitoring of lead exposure (74). However, knowledge on the kinetics of $\mathrm{PbB}$ is incomplete, as it is regarding the metabolism of lead in the other tissues of the body (74), which is a phenomenon that $\mathrm{PbB}$ may mirror.

In the present article we report a study of the decay pattern of lead in the blood of lead-exposed subjects after the end of exposure. This decay pattern could be interpreted by a metabolic model.

\section{Subjects and methods}

\section{Subjects and sampling}

The first group to be studied was 23 male ex-lead workers (table 1). Their mean age was 55 years and their mean exposure time was 23 years. The $\mathrm{PbB}$ was usually determined at the end of exposure and then at varying intervals. For ten subjects $\mathrm{PbB}$ was determined once, or more often, a year. For one worker (number 101), no information was available concerning the first year after the end of exposure. For 12 subjects (numbers 104-115), several determinations were made during the first year, then at year seven, and then again from year nine on about twice a year. For one subject (num-

1 Department of Occupational Medicine, University Hospital, Lund, Sweden.

2 Department of Radiation Physics, Lund University, Malmö General Hospital, Malmö, Sweden.

Reprint requests to: Dr A Schütz, Department of Occupational Medicine, University Hospital, S-221 85 Lund, Sweden. ber 102) there was a lack of data between 3.5 and 9.6 years after the end of exposure.

In addition 17 male lead workers temporarily removed from exposure were investigated (table 2). Their mean age was 49 years, and their mean exposure time was 11 years. The reason fo: removal from exposure was high $\mathrm{PbB}$ levels (generally about $3.0 \mu \mathrm{mol} / \mathrm{l}$ or more). Twelve of the workers were transferred from a smeltery to a nearby plant, the work in which did not involve lead exposure. The $\mathrm{PbB}$ level was generally determined when the workers left the smeltery and then once a week for three weeks; later PbB measurements were made once every two to four weeks.

Furthermore, two male volunteers, who had been unexposed occupationally, but who had been exposed to a single short heavy lead dose, were included (table 2). Details on these two subjects have been published elsewhere (56).

Spot determinations of "background" PbB levels were made for $\mathbf{4 7}$ healthy workers not occupationally exposed to lead. They lived in the same county as the exposed subjects and were all blue-collar workers. Their average $\mathrm{PbB}$ level was $0.3 \mu \mathrm{mol} / \mathrm{l}$. In this connection, it may be mentioned that, for 15 workers in a glue production plant located close to the nonlead resort of the temporarily removed smeltery workers, the average $\mathrm{PbB}$ level was 0.5 (range $0.3-0.7$ ) $\mu \mathrm{mol} / \mathrm{l}$.

\section{Medical examinations}

For most of the subjects, an occupational and medical history, including alcohol habits, was obtained. Venous blood samples were analyzed for lead (see the section Blood Lead Determinations), hemoglobin, sedimentation rate; red and white cell counts; calcium, 
phosphate, and creatinine concentrations; and alkaline phosphatase and gamma glutamyl transferase activities in serum. A urine sample was analyzed for albumin and glucose.

Among the ex-lead workers, detailed medical information was lacking for four. Among the 19 remaining, 12 had earlier been removed (at least once) temporarily from lead exposure because of a high $\mathrm{PbB}$ level and/or a high delta-aminolevulinic acid level in the urine. One subject was clinically diagnosed as lead poisoned (upper abdominal pain, constipation, neuropathy, and slight anemia) at the time when his exposure ended. No one else had been treated in a hospital because of lead poisoning. One worker had a clinically silent chronic lymphatic leukemia, and one had a type 2 diabetes treated with diet only. Three persons had slight increases in their serum creatinine levels, and two others showed slight albuminuria. Three subjects had somewhat increased gamma glutamyl transferase activities, in their serum, two of whom were known to abuse alcohol.

Among the 17 temporarily removed lead workers, detailed medical information was available for 14 . Among these 14, seven had earlier been removed because of a high $\mathrm{PbB}$ level and/or a high deltaaminolevulinic acid level in their urine. None had been treated with drugs because of lead poisoning. Three subjects had slightly increased gamma glutamyl transferase activities in their serum, one of whom also had an increased alkaline phosphatase activity in his serum. One person had an isolated marginal increase in alkaline phosphatase activity in his serum.

The two subjects without previous occupational lead exposure were both in excellent health.

\section{Blood lead determinations}

Blood was obtained from the cubital vein. During the first years of the study, acid-washed heparinized sampling tubes were prepared at our laboratory. Later on, evacuated, metal-free Vacutainer ${ }^{\circledR}$ ) tubes were used.

Almost all of the PbB determinations were made in the same laboratory and by the same method. The samples were wet-ashed, and lead was complexed with dithizone, extracted, and determined by flame atomic absorption spectrometry (AAS) $(55,56)$. The detection limit was $0.05 \mu \mathrm{mol} / \mathrm{l}(10 \mu \mathrm{g} / \mathrm{l})$.

Each analytical series contained six samples, two blanks containing reagents only, and four "normal" blood samples (two of them with standard lead addition). All the samples were analyzed twice. The coefficient of variation calculated from duplicate analyses of 25 samples containing $0.5 \mu \mathrm{mol} / 1$ or less was $6.6 \%$ of the mean, for 57 samples containing $0.5-1$ $\mu \mathrm{mol} / \mathrm{l}$ it was $3.9 \%$, for 58 samples containing $1-2$ $\mu \mathrm{mol} / 1$ it was $2.5 \%$, and for 60 samples containing $2-3.5 \mu \mathrm{mol} / \mathrm{l}$ it was $2.0 \%$.

The accuracy was tested twice each year in a Nordic interlaboratory calibration program with $6-19$ (mean
12) accepted laboratories participating on each occasion. The regression function of our results $(\mathrm{Y}, \mu \mathrm{mol} / \mathrm{l})$ on the average result of the other laboratories $(\mathrm{X})$ was $\mathrm{Y}=1.008 \mathrm{X}-0.052$. Our results for the 115 samples (range $0.2-5.6 \mu \mathrm{mol} / \mathrm{l}$ ) averaged $96.3 \%$ of the mean (range $80-112 \% ; 62 \%$ within $95-105 \%$ ) of the other laboratories. Furthermore, we participated in the UK External Quality Assessment Scheme during the latter part of the study. In the 29 samples analyzed, our results by single analysis averaged $99 \%$ of the mean $(2.40$ $\mu \mathrm{mol} / \mathrm{l}$ ) (range $90-115 \% ; 72 \%$ within $95-105 \%$ ) of the about 90 participating laboratories. Neither quality control series displayed any time trend.

During the first year of observation of subjects 104-115, the first three years of subject 102, and the six first years of subject $116, \mathrm{PbB}$ was determined by a colorimetric method after extraction with dithizone in chloroform. The detection limit was about 0.05 $\mu \mathrm{mol} / \mathrm{l}$. The results obtained by the colorimetric method averaged 105 (SD 6) $\%$ in the concentration range $0.3-1.9 \mu \mathrm{mol} / 1$ and 100 (SD 5) $\%$ in the range $2.0-5.4 \mu \mathrm{mol} / 1$ of results obtained with the flame AAS method.

From subject 116, for the following four years, determinations were made by flame AAS after precipitation of proteins with trichloroacetic acid (22). The detection limit was $0.2 \mu \mathrm{mol} / 1$, and the method error about $10 \%$.

\section{Mathematical analysis}

Three models corresponding to the sum of one, two, and three exponentials were considered for the $\mathrm{PbB}$ decay curves of each individual worker. A fixed "background" value of $0.3 \mu \mathrm{mol} / 1$ was used for all the subjects and each model. The nonlinear regression procedure in the statistical package BMDP (21) was used. This program produces estimates of the parameters which minimize the unweighted residual sum of squares using a modified Gauss-Newton algorithm. Minimum and maximum values can be specified for each parameter. Thus two parameters and their asymptotic standard deviation were estimated: an elimation rate [transformed and quoted as half-time $\left.\mathrm{T}^{1 / 2} / 1\right)$, $T^{1 / 2(2)}$, and $\left.T 1 / 2(3)\right]$ and the concentration corresponding to each compartment [Y(1), Y(2), and $\mathrm{Y}(3)]$. Confidence intervals were estimated on the assumption of asymptotic normality of the estimates. The fit of the three models was judged from comparison of the fraction of total variance in the $\mathrm{PbB}$ values explained $\left(\mathrm{R}^{2} \%\right)$. In addition plots of residuals versus time were used for checks of the validity of the model and the accuracy of the individual curve fittings.

To describe accumulation, a function of the type $Y(t)=A\{1-\exp (-B \times t)\}$, where $A$ is a scale constant, $\mathrm{B}$ an elimination constant, and t time, was fitted to the data by use of the nonlinear regression procedure in BMDP (21). 


\section{Bone lead levels}

Bone lead levels were determined in vivo from the middle phalanx of the left forefinger of 37 subjects by an X-ray fluorescence method, as described earlier (16). The detection limit was $20 \mu \mathrm{g} / \mathrm{g}$, and the method error about $15 \%$. Readings below the detection limit were assigned a value of $10 \mu \mathrm{g} / \mathrm{g}$ in the calculations. In most cases, levels derived either at duplicate measurements (16) or calculated from a series of measurements (15) were employed.

\section{Statistics}

In general, nonparametric tests were employed. For associations the Spearman's rank correlation $\left(\mathrm{r}_{\mathrm{S}}\right)$ was used, and for comparisons of duplicate measurements in the same individual the Wilcoxon's matched-pairs ranked-sign test was used. Comparisons between groups were made by the Mann-Whitney U-test. In a few instances, a single or multiple linear regression analysis was made. For establishing interindividual variations, binomial tests were employed. When more than one observation series was available for a particular individual, the value corresponding to the calculations with the best fit $\left(\mathrm{R}^{2}\right)$ of the compartment analysis was used. All P-values are two-tailed. "Statistically significant' denotes $\mathrm{P}<0.05$.

\section{Results}

The decline rate of $\mathrm{PbB}$ was, in most cases, rapid soon after end of exposure, but later on it was slower (figure 1). There was generally a gocd fit of the observed $\mathrm{PbB}$ to any of the three compartment models tested (tables 1 and 2). However, one subject (number 122) (table 1) displayed pronounced irregularities in the elimination pattern, which rendered serious suspicion of occasional, ongoing exposure. In addition the lack of $\mathrm{PbB}$ data during the first $94 \mathrm{~d}$ after the stated end of exposure probably contributed to the bad fit to any of the models tested. He has thus been disregarded in the following results. Another ex-lead worker (number 114) was excluded because of suspected lead exposure during the first month of the supposedly exposure-free period (rising $\mathrm{PbB}$ ). Furthermore, before the second observation period (from year 7 on), his $\mathrm{PbB}$ had decreased to very close to the background level, and the $T 1 / 2$ (2) was determined merely from the observations made during the first year. No conclisions as regards the kinetics of a slow compartment seem to be justified in this case.

For most of the ex-lead workers, the number of observations during the first period after the end of exposure was too few (less than four per two months) to allow reasonably accurate estimates of the decay rate of the fast compartment. Thus, for all but three (numbers 102,103 , and 123), an approximate half-time of the fast compartment [T $1 / 2(1)]$ of $30 \mathrm{~d}$ was employed. (See the following text.)
The fit of the two-compartment model (median $97 \%$, range $35-99 \%$ ) was considerably and significantly ( $P<0.0001$, Wilcoxon) better than that of the one-compartment model (median $86 \%$ ) (tables 1 and 2). The fit of the three-compartment model was similar (medians 97 versus $97 \%$ ) (table 1), though significantly ( $\mathrm{P}<0.01$, Wilcoxon) better.

When the three-compartment model was employed, the median of $Y(1)$ was 0.6 (range $0.0-2.3$ ) $\mu \mathrm{mol} / \mathrm{l}$, that of $\mathrm{Y}(2)$ was 1.4 (range $0.0-2.5$ ) $\mu \mathrm{mol} / \mathrm{l}$, that of $T^{1 / 2}(2)$ was 3.7 (range $0.3-16$ ) years, that of $Y(3)$ was 0.3 (range $0.0-2.6$ ) $\mu \mathrm{mol} / 1$, and that of $T 1 / 2(3)$ was $>100$ (range $4.9-00$ ) years.

In the following presentation, only the simplest model with a good fit, ie, the two-compartment one, will be discussed.

With the use of the two-compartment model, the decay rate in the remaining 21 ex-lead workers (table 1) had a median biological half-time of the slow compartment $\left[\mathrm{T}^{1 / 2} / 2(2)\right]$ of 5.6 years during a median postexposure period of 13 years. There was a considerable range for $T^{1 / 2}(2)$, ie, $2.3-27$ years (table 1 ).

The data were sufficient for an estimate of the halftime of the fast compartment in three of the ex-lead
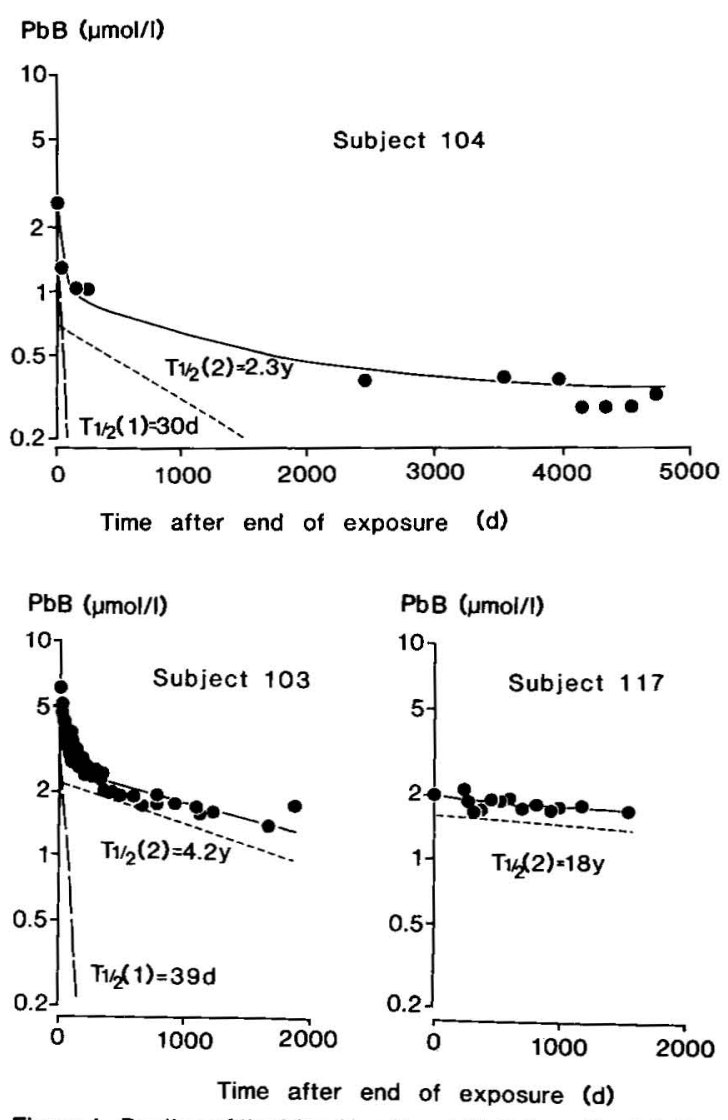

Figure 1. Decline of the blood lead level ( $\mathrm{PbB}$, logarithmic) after the end of exposure for three ex-lead workers. A twocompartment model was fitted to the data. Both compartments and their biological half-times $(T 1 / 2)$ are indicated. For subjects 104 and 117, the half-time of the fast compartment [T $1 / 2(1)]$ was assumed to be $30 \mathrm{~d}$. ( $y=$ years) 
Table 1. Kinetics of the decrease of lead in blood $(\mathrm{PbB})$ after the end of the occupational exposure of 23 ex-lead workers observed for more than one year. $\left(R^{2}=\right.$ degree of explanation, $T 1 / 2(1)=$ half-time of fast compartment, $\mathrm{T} 1 / 2(2)=$ half-time of slow compartment, $95 \% \mathrm{Cl}=95 \% \mathrm{confidence}$ interval, $Y(1)=Y$ intercept for the fast compartment, and $Y(2)=Y$ intercept for the slow compartment)

\begin{tabular}{|c|c|c|c|c|c|c|c|c|c|c|c|c|c|c|}
\hline \multirow{3}{*}{$\begin{array}{l}\text { Sub. } \\
\text { jecta }\end{array}$} & \multirow{3}{*}{$\begin{array}{c}\text { Age }^{b} \\
\text { (years) }\end{array}$} & \multirow{3}{*}{$\begin{array}{c}\text { Exposure } \\
\text { time } \\
\text { (years) }\end{array}$} & \multirow{3}{*}{$\begin{array}{c}\text { First. } \\
\text { PbB } \\
(\mu \mathrm{mol} / \mathrm{l})\end{array}$} & \multirow{3}{*}{$\begin{array}{c}\text { Obser- } \\
\text { vation } \\
\text { time } \\
\text { (years) }\end{array}$} & \multirow{3}{*}{$\begin{array}{c}\text { Number } \\
\text { of } \\
\text { sam- } \\
\text { ples }\end{array}$} & \multirow{3}{*}{$\begin{array}{c}\begin{array}{c}\text { One } \\
\text { compart- } \\
\text { ment } \\
\text { model }\end{array} \\
R^{2} \\
(\%)\end{array}$} & \multicolumn{7}{|c|}{ Two-compartment model } & \multirow{3}{*}{$\begin{array}{c}\text { Three } \\
\text { compart- } \\
\text { ment } \\
\text { model } \\
\mathrm{R}^{2} \\
(\%)\end{array}$} \\
\hline & & & & & & & \multicolumn{3}{|c|}{ Fast compartment } & \multicolumn{3}{|c|}{ Slow compartment } & \multirow[b]{2}{*}{$\begin{array}{c}R^{2} \\
(\%)\end{array}$} & \\
\hline & & & & & & & $\begin{array}{l}T 1 / 2(1) \\
\text { (d) }\end{array}$ & $95 \% \mathrm{Cl}$ & $\begin{array}{c}\mathrm{Y}(1) \\
(\mu \mathrm{mol} / \mathrm{l})\end{array}$ & $\begin{array}{l}T 1 / 2(2) \\
\text { (years) }\end{array}$ & $95 \% \mathrm{Cl}$ & $\begin{array}{c}Y(2) \\
(\mu \mathrm{mol} / \mathrm{l})\end{array}$ & & \\
\hline $101^{c}$ & 44 & 4.5 & 1.8 & 2.9 & 5 & 68 & $30^{d}$ & . & 0.0 & 3.7 & $2.0-27$ & 1.9 & 68 & 68 \\
\hline 102 & 60 & 5 & 4.2 & 15.0 & 39 & 87 & 29 & $21-47$ & 1.4 & 8.4 & $7.6-9.5$ & 2.6 & 97 & 97 \\
\hline 103 & 49 & 10 & 5.9 & 5.1 & 40 & 68 & 39 & $33-47$ & 3.0 & 4.2 & $3.4-5.7$ & 2.2 & 98 & 99 \\
\hline 104 & 54 & 35 & 2.7 & 13.0 & 11 & 87 & $30^{d}$ & . & 1.4 & 2.3 & $0.9-\infty$ & 0.7 & 95 & 95 \\
\hline 105 & 41 & 3 & 3.0 & 12.9 & 10 & 88 & $30^{d}$ & . & 0.8 & 5.6 & $4.3-8.2$ & 1.9 & 94 & 94 \\
\hline 106 & 48 & 8 & 2.9 & 12.9 & 12 & 91 & $30^{d}$ & . & 1.0 & 4.6 & $4.2-5.1$ & 1.6 & 99 & 99 \\
\hline 107 & 54 & 34 & 3.3 & 13.0 & 13 & 94 & $30^{d}$ & . & 1.1 & 3.5 & $2.8-4.7$ & 2.0 & 98 & 99 \\
\hline 108 & 30 & 7 & 3.7 & 12.9 & 12 & 91 & $30^{d}$ & . & 1.2 & 4.6 & $4.2-5.2$ & 2.2 & 99 & 100 \\
\hline 109 & 59 & 27 & 2.6 & 12.9 & 12 & 79 & $30^{d}$ & . & 1.0 & 5.1 & $4.5-5.8$ & 1.2 & 99 & 99 \\
\hline 110 & 56 & 26 & 3.8 & 12.9 & 12 & 51 & $30^{d}$ & . & 1.7 & 7.6 & $6.7-8.8$ & 1.8 & 99 & 100 \\
\hline 111 & 65 & 45 & 3.3 & 12.8 & 12 & 86 & $30^{d}$ & . & 1.0 & 9.4 & $7.9-11.5$ & 2.0 & 97 & 98 \\
\hline 112 & 51 & 33 & 3.2 & 12.8 & 10 & 95 & $30^{d}$ & . & 0.5 & 5.8 & $5.0-6.9$ & 2.3 & 98 & 99 \\
\hline 113 & 66 & 44 & 3.0 & 11.2 & 9 & 96 & $30^{d}$ & . & 0.5 & 5.6 & $4.7-6.8$ & 2.3 & 98 & 100 \\
\hline 114 & 31 & 4 & 2.4 & 10.4 & 8 & 98 & $30^{d}$ & . & 0.2 & 0.8 & $0.5-2.5$ & 2.0 & 98 & 99 \\
\hline 115 & 63 & 45 & 2.2 & 9.4 & 6 & 96 & $30^{d}$ & . & 0.3 & 3.9 & $3.3-4.8$ & 1.6 & 99 & 99 \\
\hline 116 & 67 & 10 & 4.3 & 13.2 & 9 & 82 & $30^{d}$ & . & 1.4 & 8.7 & $6.7-12.4$ & 2.5 & 97 & 97 \\
\hline $117^{\mathrm{c}}$ & 59 & 27 & 2.0 & 4.2 & 14 & 31 & $30^{d}$ & . & 0.1 & 18 & $8.1-0.0$ & 1.6 & 35 & 37 \\
\hline 118 & 58 & 22 & 1.9 & 4.9 & 10 & 78 & $30^{d}$ & . & 0.4 & 6.5 & $4.3-13.8$ & 1.2 & 91 & 91 \\
\hline 119 & 65 & 30 & 2.8 & 4.6 & 13 & 86 & $30^{d}$ & . & 0.8 & 4.7 & $4.0-5.8$ & 1.8 & 98 & 97 \\
\hline 120 & 65 & 33 & 2.3 & 4.6 & 14 & 64 & $30^{d}$ & . & 0.6 & 9.5 & $6.2-21.3$ & 1.3 & 89 & 89 \\
\hline 121 & 65 & 14 & 1.8 & 4.3 & 17 & 78 & $30^{d}$ & . & 0.4 & 4.3 & $3.3-6.4$ & 1.0 & 92 & 92 \\
\hline 122 & 61 & 24 & $1.8^{\mathrm{e}}$ & 3.6 & 12 & 9 & $30^{d}$ & . & 4.8 & 0.0 & $\infty-\infty$ & 1.4 & 0 & 13 \\
\hline 123 & 65 & 38 & 2.0 & 1.7 & 12 & 27 & 7 & $2-\infty$ & 0.3 & 27 & $5.5-\infty$ & 1.5 & 50 & 50 \\
\hline
\end{tabular}

a Number 101 was a cast bronze founder, number 102 a spray painter, numbers 103-115 storage battery workers, number 116 a wire lead coater, and numbers $117-123$ smeltery workers.

b At the end of exposure.

c Numbers 101 and 117 are identical with numbers 201 and 217, respectively, in table 2.

d When fewer than four samples were obtained during the first two months after the end of exposure, the T1/2(1) was assumed to be $30 \mathrm{~d}$.

e Sample obtained $94 \mathrm{~d}$ after the end of exposure.

Table 2. Kinetics of the decrease of the blood lead $(\mathrm{PbB})$ levels during a temporary cessation of occupational exposure among 17 lead workers observed for less than one year and among two volunteers who had a short, heavy exposure. $\left(R^{2}=\right.$ degree of explanation, $T 1 / 2(1)=h a l f-t i m e$ for the fast compartment, $\mathrm{T} 1 / 2(2)=$ half-time of the slow compartment, $95 \% \mathrm{Cl}=95 \%$ confidence interval, $Y(1)=Y$ intercept for the fast compartment, $Y(2)=Y$ intercept for the slow compartment)

\begin{tabular}{|c|c|c|c|c|c|c|c|c|c|c|c|}
\hline \multirow{3}{*}{$\begin{array}{l}\text { Sub- } \\
\text { ject }\end{array}$} & \multirow{3}{*}{$\begin{array}{c}A^{A g e^{b}} \\
\text { (years) }\end{array}$} & \multirow{3}{*}{$\begin{array}{l}\text { Expo- } \\
\text { sure } \\
\text { time } \\
\text { (years) }\end{array}$} & \multirow{3}{*}{$\begin{array}{c}\text { First } \\
\text { PbB } \\
(\mu \mathrm{mol} / \mathrm{l})\end{array}$} & \multirow{3}{*}{$\begin{array}{l}\text { Obser- } \\
\text { vation } \\
\text { time } \\
\text { (d) }\end{array}$} & \multirow{3}{*}{$\begin{array}{c}\text { Number } \\
\text { of } \\
\text { sam- } \\
\text { ples }\end{array}$} & \multirow{3}{*}{$\begin{array}{c}\begin{array}{c}\text { One } \\
\text { compart- } \\
\text { ment } \\
\text { model }\end{array} \\
R^{2} \\
(\%)\end{array}$} & \multicolumn{5}{|c|}{ Two-compartment model } \\
\hline & & & & & & & \multicolumn{3}{|c|}{ Fast compartment } & \multirow{2}{*}{ 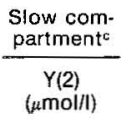 } & \multirow{2}{*}{$\begin{array}{c}R^{2} \\
(\%)\end{array}$} \\
\hline & & & & & & & $\begin{array}{l}T 1 / 2(1) \\
\text { (d) }\end{array}$ & $95 \% \mathrm{Cl}$ & $\begin{array}{c}\mathrm{Y}(1) \\
(\mu \mathrm{mol} / \mathrm{l})\end{array}$ & & \\
\hline $201^{d}$ & 43 & 3 & 6.7 & 189 & 20 & 87 & 26 & $21-35$ & 3.6 & 2.6 & 97 \\
\hline 202 & 59 & 23 & 4.5 & 209 & 12 & 87 & 43 & $25-147$ & 1.2 & 2.7 & 92 \\
\hline \multirow[t]{2}{*}{$203^{e}$} & 59 & 22 & 4.2 & 172 & 10 & 94 & 69 & $38-337$ & 2.1 & 1.9 & 96 \\
\hline & 60 & 23 & 5.4 & 118 & 14 & 96 & 49 & $36-75$ & 2.8 & 2.3 & 98 \\
\hline 204 & 53 & 22 & 4.0 & 239 & 12 & 88 & 37 & $25-74$ & 1.3 & 2.2 & 95 \\
\hline 205 & 38 & 14 & 3.9 & 48 & 7 & 89 & 14 & $7-\infty$ & 1.2 & 2.2 & 92 \\
\hline 206 & 60 & 5.5 & 3.0 & 112 & 11 & 92 & 28 & $18-61$ & 1.1 & 1.5 & 96 \\
\hline 207 & 52 & 29 & 3.0 & 218 & 12 & 73 & 63 & $20-\infty$ & 0.5 & 2.0 & 75 \\
\hline \multirow[t]{2}{*}{$208^{e}$} & 28 & 3.5 & 3.4 & 114 & 10 & 94 & 34 & $24-55$ & 1.5 & 1.7 & 98 \\
\hline & 29 & 4.0 & 3.2 & 115 & 11 & 94 & 24 & $18-36$ & 1.2 & 1.6 & 99 \\
\hline 209 & 48 & 7.5 & 3.5 & 171 & 11 & 78 & 13 & $8-38$ & 1.3 & 1.8 & 88 \\
\hline 210 & 58 & 3.5 & 3.9 & 160 & 11 & 92 & 47 & $28-139$ & 1.5 & 1.8 & 95 \\
\hline 211 & 59 & 13 & 2.8 & 155 & 12 & 54 & 8 & $5-18$ & 0.6 & 1.9 & 89 \\
\hline 212 & 49 & 10 & 3.5 & 238 & 13 & 59 & 7 & $5-10$ & 0.8 & 2.4 & 96 \\
\hline 213 & 51 & 1.5 & $3.0^{f}$ & 120 & 10 & 87 & 20 & $14-34$ & 1.9 & 1.6 & 97 \\
\hline 214 & 40 & 1.0 & 3.5 & 155 & 12 & 97 & 50 & $38-75$ & 2.0 & 1.0 & 99 \\
\hline 215 & 50 & 1.0 & 3.3 & 147 & 9 & 84 & 24 & $19-35$ & 1.4 & 1.7 & 98 \\
\hline 216 & 29 & 0.3 & 3.5 & 83 & 11 & 97 & 42 & $24-171$ & 2.4 & 0.9 & 97 \\
\hline $217^{d}$ & 59 & 26 & 3.0 & 111 & 9 & 96 & 63 & $31-\infty$ & 1.5 & 1.2 & 97 \\
\hline 318 & 33 & 0.0001 & 2.1 & 215 & 12 & 94 & 27 & $17-62$ & 1.4 & 0.1 & 94 \\
\hline 319 & 37 & 0.0001 & 2.3 & 500 & 13 & 97 & 44 & $32-71$ & 1.7 & 0.1 & 97 \\
\hline
\end{tabular}

a Number 201 was a cast bronze founder, numbers 202-205 demolition workers, numbers 206 -217 smeltery workers, and numbers 318 - 319 volunteers.

b At the end of exposure.

c $T^{1} 1 / 2(2)$ is assumed to be 5 years.

- Numbers 201 and 217 are identical to numbers 101 and 117, respectively, in table 1 .

- Two subjects were studied twice. In the statistical calculations, the decay pattern with the best fit was used.

1 Sample obtained $15 \mathrm{~d}$ after the end of exposure. 
workers (numbers 102, 103, and 123) (table 1) and in the 17 temporarily removed lead workers (table 2 ). The observation period in the latter group was too short for an accurate estimation of the half-time of the slow compartment $\left[T^{1 / 2(2)}\right]$. Thus, in the calculation of $T^{1 / 2(1)}$ for these subjects, an approximate $T^{1 / 2}(2)$ of 5 years (see the preceding text) was used as being the best estimate. The median $T^{1 / 2}(1)$ for the 20 subjects was $29 \mathrm{~d}$. Their median observation time was $155 \mathrm{~d}$. The range of $T^{1 / 2}(1)$ was considerable $(7-63 \mathrm{~d}$ ) (table 2) for subjects 203 and 208 , the $T^{1} 1 / 2(1)$ with the best fit, $49 \mathrm{~d}$ and $24 \mathrm{~d}$, respectively, being used. The decay curves with the shortest and next longest $T^{1 / 2(1)}$, respectively, are shown in figure 2.

When, in two subjects (numbers 203 and 208) (table 2), the decay pattern was studied during two periods of temporary removal from exposure, 0.5 and 1.0 years apart, the decline rates of $\mathrm{PbB}$ were compatible.

The two formerly occupationally unexposed subjects had a $T^{1 / 2(1)}$ of 27 and $44 \mathrm{~d}$ (table 2).

The $Y$ intercept of the fast compartment $[Y(1)]$ had a median of 0.8 (range $0.0-3.0) \mu \mathrm{mol} / \mathrm{l}$ for the $21 \mathrm{ex}$ lead workers (table 1), and 1.3 (range $0.5-3.6$ ) $\mu \mathrm{mol} / \mathrm{l}$ for the 17 temporarily removed ones (table 2 ). The difference was statistically significant $(P=0.007$, MannWhitney).

The $\mathrm{Y}$ intercept of the slow compartment [Y(2)] had a median of 1.8 (range $0.7-2.6) \mu \mathrm{mol} / 1$ for the 21 exlead workers (table 1) and a median of 1.8 (range 0.92.7) $\mu \mathrm{mol} / 1$ for the 17 workers temporarily removed from exposure (table 2). The groups were, of course, not significantly different. For both of the two occupationally unexposed subjects, $\mathrm{Y}(2)$ was $0.1 \mu \mathrm{mol} / \mathrm{l}$.

For the 21 ex-lead workers, Y(2) made up for a median of 68 (range 33-100) \% of the combined compartments [Y(1) plus $\mathrm{Y}(2)]$, whereas for the workers

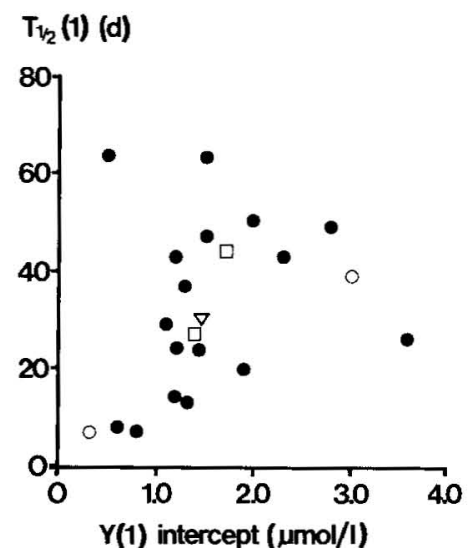

Figure 3. Relationship between the half-time $\left[T^{1 / 2(1)}\right]$ and the $Y$ intercept $[Y(1)]$ of the fast compartment in a twocompartment model fitted to the decline of the blood lead $(\mathrm{PbB})$ levels after the end of exposure. Closed circles and open squares denote lead workers and volunteers, respectively, in table 2; open circles and triangles denote ex-lead workers in table 1 . (Circles $=$ subjects studied up to 5 years, triangles $=$ subjects studied more than 5 years)
$\mathrm{PbB}(\mu \mathrm{mol} / \mathrm{l})$
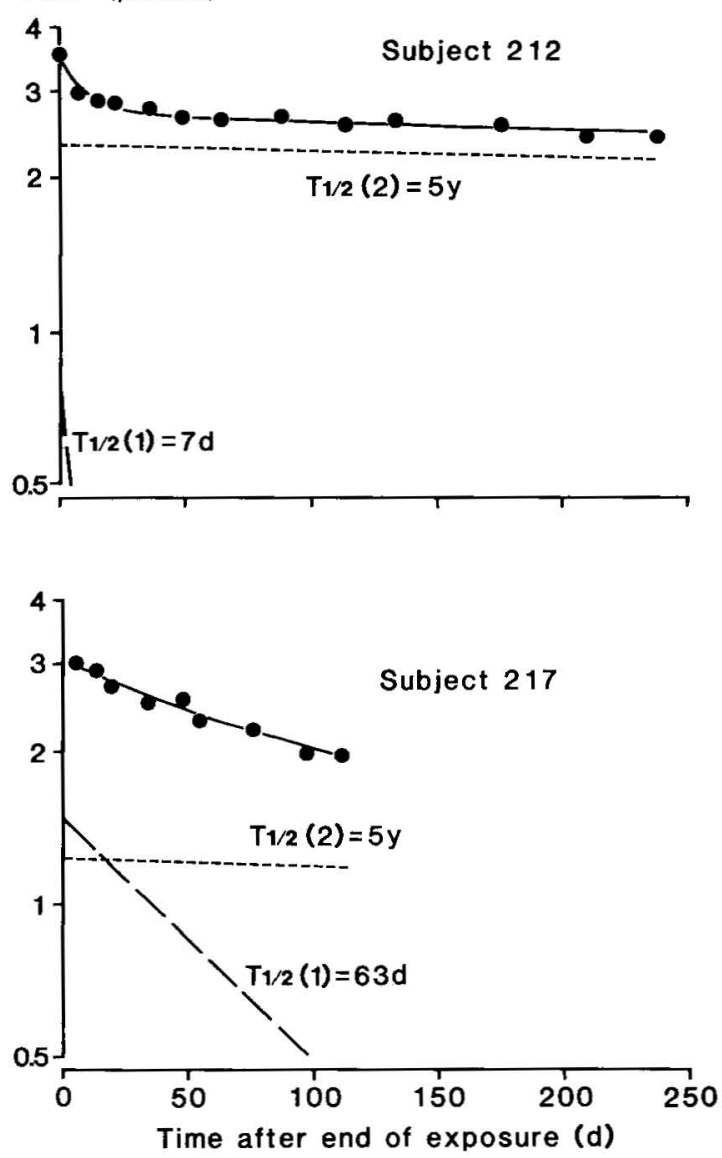

Figure 2. Decline of the blood lead level ( $\mathrm{PbB}$, logarithmic) in two lead workers temporarily removed from exposure. A twocompartment model with a biological half-time $\left(T^{1 / 2}\right)$ of 5 years for the slow compartment was fitted to the data. Both compartments and their half-times are indicated (From subject 217, the first blood sample was taken $6 \mathrm{~d}$ after the end of exposure.) ( $y=$ years)

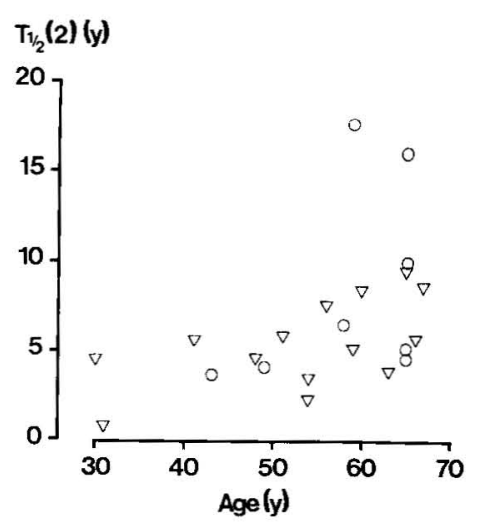

Figure 4. Relationship between age and the half-time of the slow compartment [T $1 / 2$ (2)] in a two-compartment model fitted to the decline of blood lead levels after the end of exposure. Symbols as in figure 3 . ( $y=$ years) 


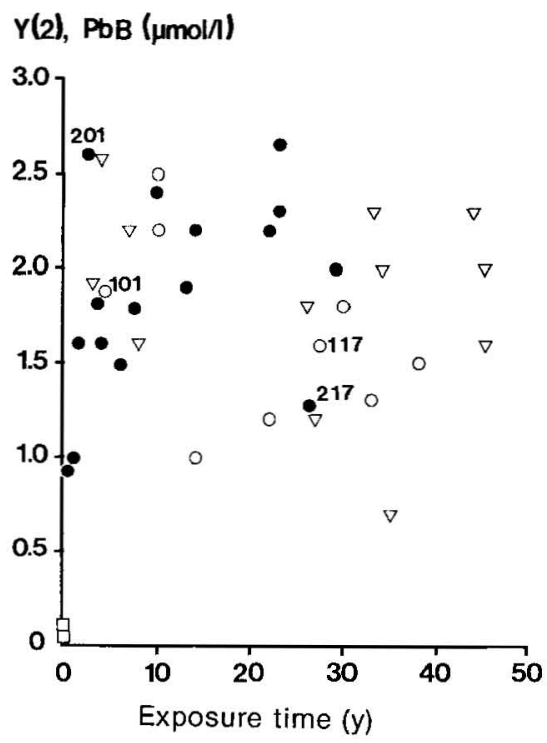

Figure 5. Relationship between time of occupational lead exposure and $Y$ intercept of the slow compartment [Y(2)] in a twocompartment model fitted to the decline of the blood lead $(\mathrm{PbB})$ levels after the end of exposure. Symbols as in figure 3 . Subjects 101 and 117 are identical with 201 and 217 , respectively. $(y=$ years $)$

\section{$\mathrm{Y}(2), \mathrm{PbB}(\mu \mathrm{mol} / \mathrm{l})$}

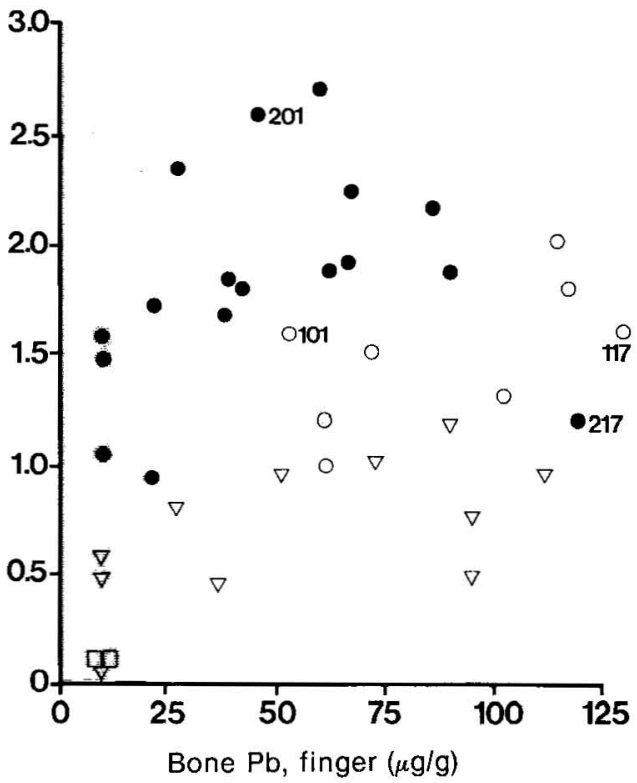

Figure 6. Relationship between the lead level in finger bone (Bone $\mathrm{Pb}$ ) and the $\mathrm{Y}$ intercept of the slow compartment $[\mathrm{Y}(2)]$ in a two-compartment model fitted to the decline of blood lead $(\mathrm{PbB})$ after the end of exposure. Symbols as in figure 3 . Subjects 101 and 117 are identical with 201 and 217 , respectively. Note: The "Y(2)" values are not the same as in tables 1 and 2 , as they have been recalculated to the time of the first bone lead determination. The symbols in the shaded area represent bone lead levels below the detection limit $(20 \mu \mathrm{g} / \mathrm{g})$. temporarily removed from exposure it was 57 (range $27-80) \%$. The difference was statistically significant $(\mathrm{P}=0.02$, Mann-Whitney). For all the lead workers, the median was $65 \%$, while the fractions were 6 and $7 \%$ for the two occupationally unexposed subjects.

$\mathrm{T} 1 / 2(1)$ correlated significantly with $\mathrm{Y}(1)\left(\mathrm{r}_{\mathrm{S}}=0.41\right.$, $\mathrm{P}=0.03$ ) (figure 3 ), but not with age, time of exposure, initial $\mathrm{PbB}, \mathrm{Y}(2)$, or the serum creatinine levels. For five out of the 20 subjects with an individually estimated $T^{1 / 2}(1)$, the linear regression line for $T^{1} 1 / 2(1)$ upon $Y(1)\left[T^{1 / 2}(1)=5.4 \times Y(1)+23\right]$ did not run through the $95 \%$ confidence interval of $T^{1 / 2}(1)$. This result showed that there was a statistically significant $(P=0.0004$, binomial test) interindividual variation for $\mathrm{T}^{1 / 2}(1)$.

The $T 1 / 2(2)$ of the ex-lead workers correlated significantly with age $\left(r_{S}=0.50, P=0.01\right)$ (figure 4$)$, but not with exposure time, observation time, initial $\mathrm{PbB}$, $\mathrm{Y}(1), \mathrm{Y}(2)$, or the serum creatinine levels. In 10 out of the 21 subjects, the linear regression line for $T^{1 / 2(2)}$ upon age $\left[\mathrm{T}^{1} 1 / 2(2)=0.15 \times\right.$ age -1.7$]$ did not run through the confidence interval of $T^{1} 1 / 2(2)$. This finding showed that there was an interindividual variation for $T^{1} / 2(2)(P<0.0001)$.

When $Y(2)$, for all 38 lead workers and the two unexposed subjects, was plotted against exposure time (figure 5), there was no significant nonparametric association. Neither was there any linear correlation. However, when an exponential accumulation curve was fitted to the data, there was a reasonable fit $\left(\mathrm{R}^{2}=49 \%, \mathrm{P}<0.001\right)$. The elimination constant was 1.2 , corresponding to a half-time of 0.6 years, and $\mathrm{Y}(2)$ leveled off at $1.8 \mu \mathrm{mol} / \mathrm{l}$.

Moreover, there was a tendency for the workers temporarily removed from exposure to have a higher $\mathrm{Y}(2)$ at a particular exposure time than the ex-lead workers. However, the difference was not statistically significant in the multiple regression analysis. Neither did the observation time display any significant association with $\mathrm{Y}(2)$.

For the 35 lead workers and the two unexposed subjects, there was a significant correlation between $Y(2)$ and bone lead content $\left(r_{S}=0.36, P=0.01\right)$ (figure 6). Multiple linear regression analysis displayed that there was an increase in $\mathrm{Y}(2)$ of $0.008 \mu \mathrm{mol} / 1 \mathrm{per} \mu \mathrm{g} / \mathrm{g}$ of bone- $\mathrm{Pb}(\mathrm{P}=0.005)$. Furthermore, the temporarily removed workers had a $\mathrm{Y}(2)$ that, on the average, was $1.0 \mu \mathrm{mol} / 1$ higher than that of the ex-lead workers. This finding was also obvious from the decrease in $\mathrm{Y}(2)$ of $0.09 \mu \mathrm{mol} / \mathrm{l}$ per year of the postexposure observation time $(\mathrm{P}<0.0001)$. Among the active workers, there seemed to be a leveling off of $Y(2)$ when the bone lead content increased. There was no such clear corresponding tendency among the retired workers.

\section{Discussion}

A multiple exponential model fitted well the decay pattern of $\mathrm{PbB}$. However, there are other possibilities, eg, power functions. Indeed, data indicating a nonlinear 
relation between the air lead level and $\mathrm{PbB}$ (eg, in references 12, 13, 19), between $\mathrm{PbB}$ and plasma lead (20, $42,45)$, and between $\mathrm{PbB}$ and the lead level in urine $(12,13,56,67)$ could favor the choice of a nonlinear model. However, elimination rates similar to ours have been reported earlier, both for subjects far less (11, $13,53)$ and far more $(14,46)$ exposed. In addition there was no indication in the present data that the elimination rates were faster in subjects with a high initial $\mathrm{PbB}$; instead the $T 1 / 2(1)$ increased with increasing $Y(1)$. Thus there are at present no serious objections against the use of a multiple exponential model, at least not in the $\mathrm{PbB}$ concentration range that we have studied.

For a few subjects, the fit was not as good. For five subjects the $R^{2}$ was $<80 \%$, and for one of them it was $0 \%$. This result may be due to the fact that, in these subjects, the $\mathrm{PbB}$ was low during a major part of the observation period and that thus the analytical error had a great impact.

It is relevant to consider whether the number of compartments is two. Different authors have proposed one $(23,68)$, two $(1,7,63,64)$, three $(4,33,43,53,66)$, four $(13,23,44,45,60)$, and even five (6) compartments in human metabolic models. The simplest model that gave a good fit in the present study was the twocompartment one. Thus there was no reason to choose a more-complicated model. Of course, from a theoretical point of view, a larger number of compartments is probable. Thus data from the two subjects exposed only to a single heavy lead dose may indicate an initial very fast decay of $\mathrm{PbB}$ (56). For most of the subjects in the present study, such a phenomenon would have remained undetected. There was probably a continuous absorption of lead from the lungs and gastrointestinal tract for some time after the end of exposure. (Sec the following discussion.) In addition the early observations were few. However, for the two subjects (numbers 208 and 216) from whom frequent observations were made during the first few days after the end of exposure, the data did not indicate any rapid initial decrease. Moreover, in addition to the relatively small number of observations, the limited observation period and the analytical method error may obscure other compartments, especially small or very slow ones. Indeed, some observations in the present study may indicate that the slow compartment really has more than one component. (See the following discussion.)

The parts of the body which constitute the two compartments must also be considered. The only organ containing lead amounts sufficiently large to cover the considerable excretion associated with the decay of the slow compartment [on the order of $0.05-0.1 \mathrm{mg} / 24 \mathrm{~h}$ in urine only, for several years (60)] is the skeleton, which contains hundreds of milligrams $(1,15,16,39$, 59). The identity between the slow compartment and the skeletal pool is also strongly supported by the association between $Y(2)$ and the bone lead content. The soft tissues, including the lung, contain only a few milligrams $(10,59)$, an amount which fits with the excre- tion during the emptying of the fast compartment.

The median half-time of the fast compartment was about one month. There may be errors that affect this estimate. It is difficult to be absolutely sure that the exposure did stop totally at a fixed date; some exposure may have continued after the formal end of exposure. For example, for the temporarily removed smeltery. workers, the worksite after removal was located only a few hundred meters from the plant. Also, the homes of the workers may have been contaminated. In addition, a worker may have a pool of lead in the lungs and the gastrointestinal tract and thus continue to absorb lead for some time after lead inhalation and ingestion have ceased. The limited data on hand - frequent measurements of two subjects - may indicate such an absorption, but mainly up to one week after the end of exposure, which is in accordance with earlier observations $(9,12,13,31,32)$. This delayed absorption is probably the reason of the present weak positive correlation between $\mathrm{T}^{1 / 2}(1)$ and $\mathrm{Y}(1)$. These possible sources of error all tend to give a somewhat too long an estimate as compared to the true half-time. Furthermore, the workers temporarily removed from exposure were not randomly selected. They were removed from exposure because of high $\mathrm{PbB}$ levels, and this occurrence might partly be the result of a slow elimination rate in those particular individuals. Another possible explanation of the slight positive association between $T^{1 / 2}(1)$ and $Y(1)$ is a bias introduced by the disregarding of possible intermediate compartments.

$\mathrm{PbB}$ is mainly present in the red cells. It could thus be suspected that the lifetime of these cells would determine the $T^{1 / 2}(1)$. However, the calculated $T^{1 / 2(1)}$ is considerably shorter than would be expected if lead were eliminated from blood only at the normal death of these cells. But lead is known to cause hemolysis, and the question can be raised of whether it could have affected the $T^{1} / 2(1)$. Hardly, at least not considerably, as there was no correlation between $T^{1 / 2}(1)$ and the initial $\mathrm{PbB}$. A negative correlation would be expected if hemolysis were important. For the lead workers temporarily removed from exposure, we had to employ an estimated $\mathrm{T}^{1} 1 / 2(2)$ of five years. However, this procedure did not affect the $T^{1 / 2}(1)$; even a $T^{1} 1 / 2(2)$ as short as one year, or as long as 10 years, would cause only slight changes in the $T^{1} / 2(1)$.

Having taken these possible errors into consideration, we still find it fully justified to conclude that the average $T^{1 / 2}(1)$ is about one month. This assumption is also compatible with various kinds of earlier data on the elimination $(1,11-14,20,27-29,36,37,40$, $46,50,53,54,56,65$ ), if a second, slow compartment is taken into consideration, and on the accumulation $(5,24,27,28,37,38,48,65,67)$ of PbB.

There was a considerable interindividual variation in $T^{1 / 2}(1)$. To some degree this occurrence may be explained by various errors in the estimates of individual decay curves. Thus the two subjects studied twice had 
a different $\mathrm{T}^{1} / 2(1)$ on the first and second occasion, a finding which could not reasonably be accounted for by real variation. It should be noted though that the half-times were not statistically significantly different, as the confidence intervals overlapped. It is difficult to explain all the variation within the population by errors; there is very probably a true interindividual variation in turnover rate, as has been observed for lead in dogs (23), as well as for other heavy metals in man [methylmercury $(58)$, cadmium $(34,71)$, chromium (70)], though the true range of the $T^{1 / 2}(1)$ may perhaps not be as large as 10 times. The interindividual variation may be due to differences in excretion, in urine and/or in feces. However, it was not associated with the serum creatinine levels, and there was no association between elimination rate and urinary lead excretion (60). One possibility is a variation in fecal excretion due to different elimination through bile and/or intestinal reabsorption. In fact, there are indications of a considerable interindividual difference in gastrointestinal absorption $(8,32)$.

The median half-time of the slow compartment was about five years. Some of the estimates are probably not too accurate because, at lower $\mathrm{PbB}$ levels, the analytical method error is more important. In addition, the true "background" $\mathrm{PbB}$ may vary somewhat between individuals, even in a population such as the Swedish one, which has low and rather homogeneous $\mathrm{PbB}$ levels. Thus a somewhat lower "background" was indicated for subject 104 in the decay curve in figure 1 . Furthermore, the number of observations was relatively low, and the observation period should preferably have been a couple of decades. For most of the ex-lead workers, we had to employ an estimated $T^{1 / 2}(1)$ of $30 \mathrm{~d}$. This procedure may have affected the $T 1 / 2(2)$, but only slightly. However, we consider the median of about five years as reasonably correct. Furthermore, there was definitely an interindividual variation in the $T^{1 / 2}(2)$. But the true range between individuals cannot be considered firmly established.

There was an increase in the $T^{1 / 2}(2)$ with increasing age. This phenomenon does not necessarily mean a decrease in the turnover rate of skeletal lead, but may have other explanations. First, senile osteoporosis may add significantly to the mobilization of lead from the skeleton and thus cause a gradual increase in $\mathrm{PbB}$ with time, which then leads to a spuriously high $\mathrm{T}^{1 / 2(2)}$. However, for the subjects followed by repeated X-ray fluorescence measurements of bone lead $(15,61)$, there was no association between age and $\mathrm{T}^{1 / 2}(2)$, and this finding is consistent with the lack of acceleration in the decrease of the bone lead content with time. Second, as lead is excreted by glomerular filtration (69), the decrease of this parameter with increasing age may cause a gradual relative increase in the $\mathrm{PbB}$ content, which would result in a spuriously high $T^{1 / 2}(2)$. We did not see any association between the serum creatinine level and the $T^{1 / 2}(2)$, but the glomerular filtration rate may decrease considerably without any rise of serum creatinine. Another possible explanation for the slight association between $T^{1 / 2}(2)$ and age is that older subjects were exposed to higher lead levels in the past than at present and consequently have a larger pool of "old lead" in a slow pool, from which lead is now returning to the blood. However, the fact that there was no significant association between time of exposure and $T 1 / 2(2)$ speaks against the importance of this phenomenon.

The presence of a lead pool in the body for a long time after the end of exposure has been obvious from a series of investigations (eg, those reported in references $15,16,26,29,47,52)$. The main lead pool is in the skeleton $(1,2,15,16,39,57,59)$. Much has been obscure considering the kinetics of the skeletal lead pool. The $T 1 / 2(2)$ (ie, elimination from the skeleton) of five years reported in the present investigation is faster than most earlier estimates of the half-time of skeletal lead (8-71 years) by different techniques ( 6 , $18,23,30,35,51,62,63,66)$. However, it is in accordance with data from some other studies $(3,17,25$, $68,72,73$ ). In addition it fits remarkably well the results of repeated X-ray fluorescence measurements of finger bone lead in ex-lead workers [a few of whom are identical with the present subjects $(15,61)]$. There are several possible explanations for the differences, ie, the method employed, the part of the skeleton assayed (in our case a reflex of the lead release from the whole skeleton), and the observation time in relation to exposure.

The $\mathrm{Y}$ intercepts $\mathrm{Y}(1)$ and $\mathrm{Y}(2)$ reflect the influence on $\mathrm{PbB}$ by the fast and the slow compartment, respectively. The relation between $\mathrm{Y}(1)$ and $\mathrm{Y}(2)$ varied considerably between different individuals, probably because of the exposure history. Thus, in an individual with a short, heavy exposure, the $Y(1)$ should dominate, while in subjects exposed for many years, though only slightly lately, Y(2) should be more important. It is interesting to note that, overall in the present study, Y(2) made up for as much as $1.8 \mu \mathrm{mol} / \mathrm{l}$, corresponding to $65 \%$ of the $\mathrm{PbB}$ concentration, and that it ranged upward as far as $2.7 \mu \mathrm{mol} / 1$ and $100 \%$. This is a larger fraction than has earlier been assumed $(1,12,30,41,53)$. The difference may be due to the intensity and time of exposure and the time of observation. The large impact of skeletal lead on $\mathrm{PbB}$ is important from a practical point of view, as the fraction of $\mathrm{PbB}$ which mirrors the slow compartment decreases only slowly, even after complete removal from exposure.

As has already been mentioned, the slow compartment probably mainly reflects the lead level in the skeleton, which is strongly supported by the association between $Y(2)$ and the lead level in finger bone. The retired workers were lower in $Y(2)$ in relation to finger bone lead than the active ones. In the former, $\mathrm{Y}(2)$ may mainly reflect the lead pool in the slow bone lead compartment $(53,63)$, represented by the mainly cortical (or compact) finger bone; in the latter the fast 
trabecular (or cancellous) bone pool may be more important (57). But, in addition, in the active workers, Y(2) may also be affected by a small, intermediately fast pool, perhaps contained mainly in the liver, the kidneys $(10,59)$, and the skeleton (an even faster pool than the trabecular one). When the data of subject 103 in figure 1 is closely examined, one may, in fact, anticipate more than one component in the slow compartment.

The impact of organs other than the skeleton on $\mathrm{Y}(2)$ may be indicated by the accumulation pattern of $\mathrm{Y}(2)$ with increasing exposure time. A steady state was reached already within a couple of years. This period is faster than in trabecular bone (57); the turnover of cortical bone is much slower $(15,61)$. The accumulation pattern may also be affected by the nonlinear behavior of lead in erythrocytes $(19,40,43)$. This phenomenon may also be the cause of the apparent leveling off of $\mathrm{Y}(2)$ upon lead in finger bone in active workers (but not in the retired ones, who had lower $\mathrm{PbB}$ levels).

There was a considerable interindividual variation in $\mathrm{Y}(2)$ at a particular exposure time. One obvious explanation is variations in the intensity of exposure. An additional explanation may be the interindividual variations in lead metabolism seen in this study, as well as in earlier ones $(8,32,60)$.

The variation in the kinetics of lead metabolism should mean a considerably varying risk for different individuals exposed at the same level, which, of course, is important from a practical point of view. A short $\mathrm{T} 1 / 2(1)$, as the result of a rapid excretion, is probably an advantage for the worker. On the contrary, a long $\mathrm{T} 1 / 2(2)$ may be good, as it means that the net endogenous exposure from the skeleton is low.

In many countries, lead workers are removed from lead exposure when they reach a PbB "trigger level", ("removal level"'; in Sweden at present $3.0 \mu \mathrm{mol} / \mathrm{l}$ ), and they are not allowed to return until the $\mathrm{PbB}$ concentration has decreased to a "safe level" ("return level"; $2.0 \mu \mathrm{mol} / \mathrm{l})$. In our "typical" lead worker, who had an $\mathrm{Y}(2)$ of $1.8 \mu \mathrm{mol} / \mathrm{l}$ and a T $1 / 2(1)$ of one month, this process will take as much as about six months. However, newly employed workers, who have a small $\mathrm{Y}(2)$, would display the same decay in less than a month. On the other hand, as many as $57 \%$ (24 of 42) of our workers had a Y(2) of more than $1.7 \mu \mathrm{mol} / 1$. On the assumption of a "background" level of 0.3 $\mu \mathrm{mol}$, they would reach $2.0 \mu \mathrm{mol} / \mathrm{I}$ only after a sufficiently long time had elapsed to affect the slow compartment. In the workers who were followed for a long time, $30 \%$ ( 7 of 23 ) would require more than a year to reach the "safe level." These assumptions are in accordance with observations of workers removed from exposure (49).

\section{Acknowledgments}

This study was supported by grants $79-72$ and $82-160$ from the Swedish Work Environment Fund.
Valuable help and advice was given in different ways by Mr N-E Winquist, L Ahlgren, PhD, R Attewell, MSc, B Gullberg, BSc, B Haeger-Aronsen, MD, H Berven, MD, S Mattsson, PhD, L Sundell, MD, T Tejler, MD, and S Tejning, MD. Excellent technical or secreterial assistance was given by Ms A Akantis, Ms Å Amilon, Ms A-P Björklund, Ms E Jonasson, Ms L Larsson, Ms G Lennartsson, Ms M Lindborg, Ms K Lindqvist, Ms U Lovén, Ms K Parker, Ms G Persson, Ms I Sandell, and Ms S Skyborn.

\section{References}

1. Ahlgren L, Haeger-Aronsen B, Mattsson S, Schütz A. In-vivo determination of lead in the skeleton after occupational exposure to lead. Br J Ind Med 37 (1980) $109-113$.

2. Ahlgren L, Lidén K, Mattsson S, Tejning S. X-ray fluorescence analysis of lead in human skeleton in vivo. Scand J Work Environ Health 2 (1976) 82-86.

3. Araki S, Katsuyuki M, Yanagihara S, Ushio K. A comparison of the diminution rates of lead in blood and lead mobilized by CaEDTA after termination of occupational exposure: A long-term observation in two lead workers. J Toxicol Clin Toxicol 20 (1983) 475-486.

4. Batschelet E, Brand L, Steiner A. On the kinetics of lead in human body. J Math Biol 8 (1979) 15-23.

5. Benson GI, George WHS, Litchfield MH, Seaborn DJ. Biochemical changes during the initial stages of industrial lead exposure. Br J Ind Med 33 (1976) 29-35.

6. Bernard SR. Dosimetric data and metabolic model for lead. Health Phys 32 (1977) 44-46.

7. Black SC, Archer VE, Dixon WC. Correlation of radiation exposure and lead-210 in uranium miners. Health Phys 14 (1968) 81-93.

8. Blake $\mathrm{KCH}$. Absorption of ${ }^{203} \mathrm{~Pb}$ from gastrointestinal tract of man. Environ Res 11 (1976) 1-4.

9. Booker DV, Chamberlain AC, Newton D, Stott ANB. Uptake of radioactive lead following inhalation and injection. Br J Radiol 42 (1969) 459-466.

10. Brune D, Nordberg GF, Wester PO. Distribution of 23 elements in the kidney, liver and lungs of workers from a smeltery and refinery in North Sweden exposed to a number of elements and of a control group. Sci Total Environ 16 (1980) 13-35.

11. Campbell BC, Merdith PA, Moore MR, Watson WS. Kinetics of lead following intravenous administration in man. Toxicol Lett 21 (1984) 231-235.

12. Chamberlain AC. Effect of airborne lead on blood lead. Atmos Environ 17 (1983) 677-692.

13. Chamberlain AC. Prediction of response of blood lead to airborne and dietary lead from volunteer experiments with lead isotopes. Proc R Soc London Ser B 224 (1985) 149-182.

14. Chamberlain MJ, Massey PMO. Mild lead poisoning with an excessively high blood lead. Br J Ind Med 29 (1972) 458-461.

15. Christoffersson J-O, Ahlgren L, Schütz A, Skerfving $\mathrm{S}$, Mattsson S. Decrease of skeletal lead levels in man after end of occupational exposure. Arch Environ Health 41 (1986) 312-318.

16. Christoffersson J-O, Schütz A, Ahlgren L, HaegerAronsen B, Mattsson S, Skerfving S. Lead in finger-bone analysed in vivo in active and retired lead workers. Am J Ind Med 6 (1984) 447-457.

17. Cohen N, Jaakola T, Wrenn ME. Lead-210 concentrations in the bone, blood and excreta of a former uranium miner. Health Phys 24 (1973) 601-609.

18. Cohen N, Spitz HB. Estimation of the skeletal content of bone-seeking radionuclides from in vivo scintillation 
measurements of their activity in the skull. In: New York University, Institute of Environmental Medicine, Radioactivity studies. Annual report, July 1, 1974 - June 30, 1975. COO-3382-14, Volume 2. New York, NY 1976, pp I.1-I.20. Cited by Holtzman RB. Application of radiolead to metabolic studies. In: Nriagu $R$, ed. The biochemistry of lead in the environment. Elsevier/NorthHolland Biomedical Press, Amsterdam 1978, pp 37-96.

19. Colombo A. The underdefined nature of the blood leadair lead relationship from biological and statistical grounds. Atmos Environ 19 (1985) 1485-1493.

20. De Silva PE. Determination of lead in plasma and studies on its relationship to lead in erythrocytes. $\mathrm{Br} \mathbf{J}$ Ind Med 38 (1969) 209-217.

21. Dixon WJ, Brown MB, Engelman L, Fraue JW, Hill MA, Jennrich RI, Toporek JD. BMDP statistical software 1981. University of California Press, Berkeley, CA 1981.

22. Einarsson O, Lindstedt G. A non-extraction atomic absorption method for the determination of lead in blood. Scand J Clin Lab Invest 23 (1969) 367-371.

23. Fisher HL. A model for estimating the inhalation exposure to radon-222 and daughter products from the accumulated lead-210 body burden. Health Phys 16 (1969) $597-616$

24. Forni A, Cambiaghi G, Sechi GC. Initial occupational exposure to lead. Chromosome and biochemical findings. Arch Environ Health 27 (1976) 73-78.

25. Gossman HH, Heilenz S. Zum Bleigehalt menschlichen Knochengewebes. Dtsch Med Wochenschr 92 (1967) 2267-2269

26. Grandjean P, Kon SH. Lead exposure of welders and bystanders in a ship repair yard. Am J Ind Med 2 (1981) $65-70$.

27. Griffin TB, Coulston F, Wills H, Russel JC, Knelson JH. Clinical studies on men continuously exposed to airborne particulate lead. In: Griffin TB, Knelson JH, ed. Lead. Georg Thieme Publishers, Stuttgart 1975, pp $221-240$.

28. Gross S. Human oral and inhalation exposures to lead: Summary of Kehoe balance experiments. J Toxicol Environ Health 8 (1981) 333-377.

29. Hesley KL, Wimbish GH. Blood lead and zinc protoporphyrin in lead industry workers. Am Ind Hyg Assoc J 42 (1981) 42-46.

30. Holtzman RB. Application of radiolead to metabolic studies. In: Nriagu R, ed. The biochemistry of lead in the environment. Elsevier/North-Holland Biomedical Press, Amsterdam 1978, pp 37-96.

31. Hursh JB, Mercer TT. Measurement of ${ }^{212} \mathrm{~Pb}$ loss rate from human lungs. J Appl Physiol 28 (1970) 268-274.

32. Hursh JB, Suomela J. Absorption of ${ }^{212} \mathrm{~Pb}$ from the gastrointestinal tract of man. Acta Radiol 7 (1968) $108-120$.

33. International Commission for Radiation Protection. Statement and recommendations of the 1980 Brighton meeting of the ICRP. Pergamon Press, New York, NY 1980, pp 64-65. (ICRP publ 30, part 2).

34. Järup L, Rogenfelt A, Elinder C-G, Nogawa K, Kjellström T. Biological half-time of cadmium in the blood of workers after cessation of exposure. Scand J Work Environ Health 9 (1983) 327-331.

35. Jaworowski $Z$. Stable and radioactive lead in environment and human body, NEIC-RR-29. Nuclear Information Center, Warsaw 1965.

36. Kang HK, Infante PF, Carra JS. Determination of blood-lead elimination patterns of primary lead smelter workers. J Toxicol Environ Health 11 (1983) 199-210.

37. Kehoe RA. The metabolism of lead in health and disease. J R Inst Publ Health Hyg 24 (1961) 81-96, $101-120,129-143,177-203$

38. Lerner S, Gartside P, Roy B. Free erythrocyte protoporphyrin, zinc protoporphyrin and blood lead in newly re-exposed smelter workers: A prospective study. Am Ind Hyg Assoc J 43 (1982) 516-519.

39. Lindh V, Brune D, Nordberg G, Wester PO. Levels of antimony, arsenic, cadmium, copper, lead, mercury, selenium, silver, tin and zinc in bone tissue of industrially exposed workers. Sci Total Environ 16 (1980) $109-116$.

40. Lynam DR, Nelson KW. Predicting return to work after medical removal required by health standards. Min Congr J (1982) 41-44.

41. Manton WI. Contribution of airbone lead to blood lead. Br J Ind Med 42 (1985) 168-172.

42. Manton WI, Cook JD. High accuracy (stable istope dilution) measurements of lead in serum and cerebrospinal fluid. Br J Ind Med 41 (1984) 313-319.

43. Marcus AH. The body burden of lead: Comparison of mathematical models of accumulation. Environ Res 19 (1979) 79-90.

44. Marcus AH. Multicompartment kinetic models for lead: II Linear kinetics and variable absorption in humans without excessive lead exposures. Environ Res 36 (1985) $459-472$.

45. Marcus AH. Multicompartment kinetic model for lead: III Lead in blood plasma and erythrocytes. Environ Res 36 (1985) 473-489.

46. McRoberts W. Alternation in the fractionated blood lead concentrations in the development of inorganic lead poisoning, and the concept of the role of "lead integration" in lead absorption. J Soc Occup Med 23 (1973) $3-18$.

47. Mindus P, Kolmodin-Hedman B. Told by her doctor to drink large amounts of water - suffered lead poisoning. Acta Med Scand 209 (1981) 425-428.

48. Neri LC, Hewitt D, Johansen H. Health effects of low level occupational exposure to lead: The Trail, British Columbia study. Arch Environ Health 38 (1983) $180-189$.

49. O'Flaherty EJ. The rate of decline of blood lead in lead industry workers during medical removal: The effect of job tenure. Fundam Appl Toxicol 6 (1986) 327-380.

50. O'Flaherty EJ, Hammond PB, Lerner SI. Dependence of apparent blood lead half-time on the length of previous lead exposure in humans. Fundam Appl Toxicol 2 (1982) 49-54.

51. Palmer HE, Heid KR, Moore RH. Lead-210 in uranium mine and mill workers. Health Phys 47 (1984) 632-634.

52. Prerovska I, Teisinger J. Excretion of lead and its biological activity several years after termination of exposure. Br J Ind Med 27 (1970) 352-355.

53. Rabinowitz MB, Wetherill GW, Kopple JD. Kinetic analysis of lead metabolism in healthy humans. J Clin Invest 58 (1970) 260-270.

54. Schlegel H, Kufner G. Longterm observation of biochemical effects of lead in human experiments. J Clin Chem Clin Biochem 17 (1979) 225-233.

55. Schütz A, Ranstam J, Skerfving S. Blood lead levels in school children in relation to industrial emission and automobile exhausts. Ambio 13 (1984) 115-117.

56. Schütz A, Skerfving S. Effect of a short, heavy exposure to lead dust upon blood lead level, erythrocyte deltaaminolevulinic acid dehydratase activity and urinary excretion of lead, delta-aminolevulinic acid and coproporphyrin. Scand J Work Environ Health 3 (1976) 176-184.

57. Schütz A, Skerfving S, Christoffersson J-O, Ahlgren L. Lead in vertebral bone biopsies from active and retired lead workers. Arch Environ Health (in press).

58. Skerfving S. Methylmercury exposure, mercury levels in blood and hair, and health status in Swedes consuming contaminated fish. Toxicology 2 (1974) 3-23.

59. Skerfving S, Ahlgren L, Christoffersson J-O, HaegerAronsen B, Mattsson S, Schütz A. Metabolism of inorganic lead in occupationally exposed humans. Arh Hig 
Rada Toksikol 34 (1983) 341-350.

60. Skerfving S, Ahlgren L, Christoffersson J-O, HaegerAronsen B, Mattsson S, Schütz A, Lindberg G. Metabolism of inorganic lead in man. Nutr Res (1985): suppl 1, 601-607.

61. Skerfving S, Christoffersson J-O, Schütz A, Welinder H, Spång G, Ahlgren L, Mattsson S. Biological monitoring, by in vivo XRF measurements, of occupational exposure to lead, cadmium, and mercury. Trace Elem Med (in press).

62. Smith FA, Hursh JB. Bone storage and release. In: Lee HK, ed. Reactions to environmental agents, handbook of physiology. Volume 9 . Williams \& Wilkinson $\mathrm{Co}$, Baltimore, MD 1977, pp 469-482.

63. Steenhout A. Kinetics of lead storage in teeth and bones: An epidemiologic approach. Arch Environ Health 37 (1982) 224-231.

64. Sterling TD, Kehoe RA, Rustagi JS. Mathematical analysis of lead burdens. Arch Environ Health 8 (1964) 44-51.

65. Stuik EJ. Biological response of male and female volunteers to inorganic lead. Int Arch Arbeitsmed 33 (1974) 83-97.

66. Sugita M. The biological half-time of heavy metals. The existence of a third, "slowest" component. Int Arch Occup Environ Health 41 (1978) 25-40.

67. Tola S, Hernberg S, Nikkanen J. Parameters indicative of absorption and biological effect in new lead exposure: A prospective study. Br J Ind Med 30 (1973) 134-141.

68. Tsuchiya K, Sugita M. A mathematical model for deriving the biological half-life of a chemical. Nord Hyg Tidskr 53 (1971) 105-110.

69. Vander AJ, Taylor DL, Kalitis K, Monev DR, Victery W. Renal handling of lead in dogs: Clearance studies. Am J Physiol 233 (1977) F532-538.

70. Welinder H, Littorin M, Gullberg B, Skerfving S. Elimination of chromium in urine after stainless steel welding. Scand J Work Environ Health 9 (1983) 397-404.

71. Welinder $\mathrm{H}$, Skerfving $\mathrm{S}$, Henriksen O. Cadmium metabolism in man. Br J Ind Med 34 (1977) 221-228.

72. Westerman MP, Pfitzer E, Eliss LD, Jensen WH. Concentration of lead in bone in plumbism. N Engl $\mathbf{J}$ Med 273 (1965) 1246-1250.

73. Wrenn ME, Cohen N, Rosen JC, Eisenbud M. In-vivo measurements of lead-210 in man. In: International Atomic Energy Agency. Assessment of radioactive contamination in man. Vienna 1972 , pp $129-145$.

74. World Health Organization. Recommended health-based limits in occupational exposure to heavy metals. Geneva 1980. (WHO tech rep ser no 647).

Received for publication: 13 May 1986 